\title{
Management Accounting and
} Service Companies' Performance: Research in Emerging Economies

\author{
Tariq Tawfeeq Yousif Alabdullah ${ }^{1}$
}

\begin{abstract}
Organizations use management accounting information in a variety of ways, and specifically management accounting information that plays a significant role in the effective management process. In addition, management accounting information contributes to the organization's performance by giving feedback on carrying out the strategic plans and completing the work, and consequently enhancing the economy of the country. However, new management accounting systems, due to its externally and future-oriented strategic characteristics, (that may avoid many of the weaknesses of conventional management accounting systems) still lack a solid base in empirical studies. The main goal of this research is to determine the effect of Strategic Management Accounting (SMA) on the Jordanian service sector's performance as one of the emerging economies. This is especially important as service sectors in several countries in the Middle East, including Jordan, have faced a notable decline in their performance. This research uses a quantitative method; the quantitative data was collected via a questionnaire. The total selected sample size for the quantitative approach was 127 companies belonging to the Jordania service sector for the fiscal year 2017. The research found that the Strategic Management Accounting influences the service sector's performance and therefore that could be used to help the service sector's managers understand the importance of accounting information for strategic decision making.
\end{abstract}

JEL classification: M40.

Keyword: Management accounting, financial performance, service sector, Jordan

${ }^{1}$ University of Basrah, Iraq 


\section{Introduction}

The service sector has a great impact on the development of a country's economy (Nyasha, S., \& Odhiambo, 2018; Latha, 2016). It is internationally accepted that the manufacturing sector contributes around $20 \%$ to the in the global economy. In several countries in Asia and the Middle East, the percentage of profits in the manufacturing sector has been close to $72 \%$ of the Jordanian profits, represented by its financial market (Amman Stock Exchange Report, 2015). The Jordanian service sector has witnessed many developments, which put it on an equal footing with some of the European and American countries. (Alabdullah, 2018; Miani \& Daradkah, 2008). The Jordanian service sector is considered as the most important sector that supports the gross domestic product (GDP). Compared with other economic sectors, such as agriculture, it contributed more than 65\% to GDP in 2009.

Increased in-house and external competition, globalisation, technological developments in computer science and engineering, with increasingly demanding customers, all created some environmental uncertainty in the service sector and changed the competition features in globally (Harris \& Mongiello, 2001), especially in the Jordanian context and its marketplace (Dwar, Bhuan, \& Jurkus, 2007). However, under this progressively competitive environment, the Jordanian service sector needs to stay competitive and reach better performance. Thus, service sector's companies need to be capable of generating and utilising more information about future events in order to upgrade business strategy and achieve advanced levels of company performance (Jermias \& Gani, 2004; Johnson \& Kaplan, 1987; Kaplan, 1983; Langfield-Smith, 1997).

More theoretically, the assumption in contingency based accounting literature is that optimal company performance depends on consistency between the accounting information systems (AIS) and some other contingency factors (like uncertainty in environment, business strategy, company size). Accounting information (AI) as output of accountancy, specifically management accounting information, significantly has an effective role in the functioning of the management process. To fulfil this requirement, management accounting systems provide managers in the company with information that has a positive impact on decision making (Horngren, 2004). Organizations use management accounting information in a variety of ways. Belkaoui (1980) characterized four usage types, such as helping management planning, facilitating organizational problem solving, aiding the examination of control functions, and facilitating operational systems management. Other authors have classified these four types into two usage streams: evaluating the performance of the management and assisting managers ability in making decisions (Tiessen \& Waterhouse, 1983).

Furthermore, management accounting information contributes to the company performance by presenting feedback to implementing the strategic plan and completing jobs. Specifically, appropriate SMA can aid managers by making them conscious and able to address company's expectations: needs of customers and competitive markets (Mia \& Paitar, 2001). In addition, ex-ante information could help meet companies' challenges resulting in appropriate output for their markets and faced by companies and supports their value added efforts relative to their competitors (Bromwch, 1990). The features of Strategic Management accounting overcome the failings of traditional management accounting systems by giving managers suitable information about the 
contemporary business environment to allow companies to obtain competitive advantages (Roslender \& Hart, 2002). Therefore, SMA enhancement to the conventional and also internally oriented approaches of Strategic Management accounting is important to meet the specific requirements of the current business environment's management, specifically on implementing strategy. While there is a growing interest to present SMA as a new management accounting system (MAS) because of its strategic features (i.e., externally and future-oriented) that can avoid several weaknesses of traditional MAS, it still lacks a solid base of empirical studies (Cadez \& Guilding, 2008; Chenhall \& Smith, 2007). In addition, some prior research that tested the link between SMA and a firm's profitability revealed mixed findings and rendering this link still unclear (Agbijule, 2005; Cades \& Guilding, 2008; Hoqae, 2005; Malmi et al., 2004; O'Connor \& Cheang, 2007). Therefore, the main goal of this research is to determine the effect of Strategic Management Accounting on Jordanian service sector performance in the emerging economies; especially noting that the service sectors in several countries in the Middle East, including Jordan, have faced a notable decline in their performance. Based on the above discussion, the present study aims to add knowledge as a contribution to the accounting management system's body of literature relating to SMA from the perspective of emerging economies, and in Jordan as the selected context where the study is undertaken.

This research has theoretical contributions. First, it expands the existence of SMA literature by providing information for evaluating companies' performance via utilizing non-financial and financial performance indicators, whereas previous studies have given more attention to financial indicators, especially in Jordan. Second, while previous empirical SMA studies predominately focused on manufacturing industries (Cadez, 2002; Cravens \& Guilding, 2001; Guilding et al., 2000), the present study contributes/adds to the existing literature on SMA in general by identifying the extent of accounting information usage in service sector in developing countries. Regarding the practical implications of the current study, most accounting and management academics consider the practical implications as a vital thing that academic and scholar research identifies its relevance and implications to practice. Thus, the current paper presents such implications and its usefulness for practitioners, primarily top management of service sector.

\subsection{Strategic Management Accounting}

Since the time Simmonds came with the term of SMA in one of his articles in the early nineteen eighties, some other studies had followed his study to refine the SMA meaning and concept; and, because there was evidence regarding the SMA's association in both management accounting (MA) and marketing management (MM) literature, this brought attention to the SMA concept (Gailding et al., 2000; Ruslender \& Hart, 2002; Lord, 1996). In 1981, Simmonds came up with the term SMA to analyse the MA data consisting of information regarding the business and its competitors. In addition, SMA had the aim of developing and monitoring business strategy. In this study of Simmonds, SMA was identified through its external emphases focusing on information useful for competitive advantage.

Pradhan, Swain and Dash (2018) attempted to develop a model of the adoption of management accounting technique and their effect on improving the performance of the supply-chain, in addition to overall company performance. Their study showed that the adoption of various management accounting techniques on supply chain activities is the most appropriate (effective) strategy to boost the performance of the firm. 
Dearman, Lechner and Shanklin (2018) investigate factors affecting the demand for management accounting information by evaluating entrepreneurs' decisions for the preparation of business plans supporting applications to obtain funds. The implications of the findings supported the demand for managerial accounting information which is based, to some extent, on managers' need for information to support optimal management decisions.

Bromwich (1990) explained SMA as the system that provides and analyses financial information including the company's competitors' costs, product markets, and the monitoring of the company's strategy and its competitors during a period of time. Bromwich demonstrated that SMA is not just data collection concerning the companies and their competitors through seeking the way of evaluation to evaluate company's competitive advantage.

Bromwch and Bhimuni (1994) showed SMA as a way of providing and analysing the companies' product markets via financial information, and also to provide, analyse and monitor the company's strategies and its competitors in the marketplace. Tomkins and Carr (1996) viewed SMA as lacking a conceptual framework. Similarly, Coad (1996) sees SMA as an emerging management accounting area with no exact identity and having an uncertain development in the future.

Lord (1996) identified the collecting of information about competitors, utilization of cost decreasing possibilities, and matching of accounting with strategic position as three elements of SMA; while Roslender $(1995,1996)$ referred to SMA in terms of accounting for strategic positioning, an idea which is very closely linked to Porter's concept of competitive advantage (Porter, 1980; Porter \& Millar, 1985). The argument by Roslender was that SMA is one of a number of different generic approaches that are found within the overall theme of accounting for strategic positioning.

SMA practices are believed by Gailding, Cravins, and Tayles (2000) to be characterized by one of the following elements: external business environmental-orientation, marketing orientation, a long term orientation to the future. Ruslender and Hurt (2003) explained that SMA is an accounting approach to strategic-positioning, an attempt to merge insights from marketing management and also management accounting in an SM framework. Yet, there is limited unanimity concerning what shapes SMA (Cades \& Gailding, 2008). Such case of conflict in viewing the concept of SMA and its contents has led researchers to look into which techniques of Management Accounting could carry strategic orientation and thus are shown to be as the technique of SMA. Gailding (1999) dealt with the benefit of "competitor-focused accounting".

Further, the set of techniques belonging to SMA were provided by Guilding et al, (2000) who explained that the criteria for dealing with accounting techniques were the same as "strategic." It is worth remembering that much of traditional management accounting (MA) relied on only a one year period. These features are inconsistent with a strategic orientation. The key features of SMA as a strategy implies a long term, future orientation. The authors accordingly demonstrated that these features might be a positive instrument to determine appropriate accounting techniques for strategic management accounting. As for this perspective, the techniques must be embodied degrees of these two orientations. In line of how Guilding et al., (2000) collected twelve techniques of SMA from the previous studies in the literature and then Cravins and Gailding (2001) further added another three techniques.

Cades and Gailding (2008) emphasized the participation of strategic accountants in cross-functional teams, and the SMA practice of guided management accounting with 
an emphasis on operational issues. Many other authors who agree that this shift had led to many new terms, such as "strategic accounting" share this view. They have also defined new active roles for accountants, such as being key players in analysing broader business management and in counselling customers. These roles had not been assigned to them before. Cadez and Guilding further came with 16 techniques of SMA from these studies. They categorized these techniques into five broad categories, three of these embodying themes of management accounting dealt with in management accounting literature. These three are (1) costing, (2) planning, control, and performance measurement, and (3) decision-making. The other two categories were "competitor accounting" and "customer accounting".

However, the focus of this study is the information related to the services sector, especially about customers that was obtained externally. The main reason behind the selection of this information was because it involves customer-focused techniques or customer accounting (which yields information regarding the customers) and it includes the most widely applied techniques in the service sector (Begum, Alam, Alam, \& Awang, 2015; Cadez, 2006). Moreover, the significance of identifying which customers contribute to an organization's profit has been given a lot attention by researchers. In addition, there was the idea that not every unit of revenue contributes equally to profits; some customers are more profitable than others (Kaplan \& Narayanan, 2001; Reinartz \& Kumar, 2003).

\subsection{Organizational Performance}

Organizational performance has been presented as an essential dependent variable in accounting-based contingency research as it provides the means for setting the suitable fit between the organizational accounting information systems design and its contextual variables (Chenhall, 2003; Jusoh, Ibrahim, \& Yuserrie, 2008). Moreover, most related studies look for variables that lead to variations in organizational performance (March $\&$ Sutton, 1997). The general idea of the concepts of organizational performance is focused on either efficiency or effectiveness, because organizations should be profitable in the long run to survive (March \& Sutton, 1997).

Nevertheless, performance measurement systems, by their nature, cover various subjects, thus, encouraging this study to investigate it from different perspectives such as accounting information systems and operations management. Maas, Schaltegger, and Crutzen, (2016) surveyed previous studies in the literature covering the links and partial links between sustainability assessment, management accounting, management control, and reporting. The key results indicate that the various concepts (performance assessment, management accounting, management control, and reporting) are defined and used in different ways but mainly dealt within an isolated manner.

Otley (1999) looks at performance measurement systems from a management accounting perspective as systems that provide the information thought to be of use to managers in conducting their work and to aid organizations in developing and maintaining practical patterns of behaviour. Neily, Gregory, and Plutts (1995) define performance measurement systems as "the set of metrics used to quantify both the efficiency and effectiveness of actions".

Abdel-Maksoud, Cheffi, and Ghoudi, (2016) investigate the links between the extent of shop floor involvement and also the deployment of (MAS) tools; they are, advanced management accounting and non financial performance measurements . The results indicate that the extent of shop floor involvement could mediate the advanced 
management accounting and non financial performance measurements link; thus, it accounts for an essential omitted relationship in comprehending this link.

Moreover, Forza and Salvadore (2000) defined systems of performance measurement as an information system (IS) supporting top management regarding the performance management accomplishing two main purposes. The first is related to allowing and structuring communication among all the organizational units involved in the process of target setting. The second lies in processing, delivering information, and collecting people performance, activities, products, processes, and business units.

Ittner, Larcker, and Randall (2003) point out three dimensions for performance measurement systems. First, they provide information that allows the firm to identify the strategies offering the highest potential for achieving the company's objectives. Second, they align management processes, such as objectives setting and decision making. Third, performance evaluation was done with reference to the accomplishment of the chosen strategic target. In fact, there have been too many authors who have illustrated the term performance measurement systems (Franco-Santos et al., 2007). However, performance measurement has an important role in the organization, and it must be selected according to the variables based on context, such as strategy, environmental uncertainty, technology, and so on (Otley, 1980).

However, while the idea of organizational performance is comparatively easy to understand, it is difficult to measure and evaluate. This difficulty is evidenced by the on-going debate on whether performance is a one-dimensional concept or a multidimensional one, whether it should be measured by qualitative or quantitative data, whether it involves objective or subjective data (Dess \& Robinson, 1984; March \& Sutton, 1997). In this regard, it is worth here to differentiate between the objective and subjective data method; objective data refers to the data given by the organization, while the subjective measurements call upon the perception of the respondent (Dess \& Robinson, 1984). Information regarding performance is significant in diverse ways to the different stakeholders within a business. For example, owners and investors are interested in company performance to ensure that their investment decisions are the right ones. Managers look at the performance of a company's sub-units as a technique of prioritizing the allocation of resources (Duursema, 1999).

In a strategic sense, performance measurement is seen as a significant approach of keeping an organization on its way in realizing the company's targets. In addition, it is a system for monitoring that employed via the shareholders of an organization where the separation between ownership and management exists (Itner \& Lurcker, 1998; Kaplan, 1984). Performance measures have to link with business strategy to be effective. A number of researchers support this view noting that performance measures need to be based on a business's strategic objectives for employees to realize and be committed to the accomplishment of those objectives (Becker \& Gerhart, 1996).

However, strong arguments are saying that the main performance measurements would usually include some mixture of indicators across two broad categories: financial indicators and non-financial indicators (Chenhell \& Langfiald Smith, 2007; Kaplan \& Norton, 1992; Kaplan, 1983, 1996). Therefore, the present work has utilized financial performance indicators to measure and evaluate organizational performance. Other subsections will deal with the nature and concept of non financial and financial performance measurement systems. 


\section{Literature Review and Hypotheses Development}

The existing literature shows that the usage of a broad scope of MAS information helps managers reduce high levels of uncertainty and job complexity, and also leads to successful decision making (Ferris \& Haskins, 1988; Mia, 1993). It is due to the wide use for broad scope MAS provides management with multiple options to manage their business, leading in a wide improvement in top managers' comprehension of their business performance (Bainis \& Langfeild Smith, 2003; Ferres \& Haskens, 1988; Gordan \& Narayenan, 1984; Mia, 1993).

Studies in service companies have found empirical evidence that supports the positive relationship between managers' use of the conventional management accounting information and organizational performance (Chong \& Chonge, 1997; Mia \& Clark, 1999). This empirical evidence presented in the services sectors may not be relevant in the manufacturing industry (Mia \& Patiar, 2001). Also, conventional management accounting information has become under strong criticism by scholars and practitioners (Cooper \& Kaplan, 1988; Drury, 2007) as being internally rather externally focused, expost oriented (related to past events) rather than ex-ante (related to future events), financially oriented, and according to Wilson (1995), this emphasizes short-term goals. Budiarto et al. (2018) investigated the direct link as well as the mediating link among three variables of accounting information system alignment on the firm performance. The findings reveal that accounting information developed and the commitment by the owner affects firm performance, either from the direct link or a mediated one by accounting information system alignment. They admitted that accounting information is very important for firms to compete in a highly competitive work environment. Ward (1993) argued that MAS must add an external focus such as customers' perceptions of value in addition to the traditional inward emphasis of the accounting analysis, planning, and control.

The case with traditional MA promoted MA researchers to present SMA, to overcome the disability of traditional management accounting to present the long term orientation (Cades \& Gailding, 2008; Gailding, Cravens, \& Tayles, 2000; Roslinder \& Hart, 2003).

Several studies have measured SMA techniques by using one signal item (question) in the questionnaire for each technique (Cadez, 2006; Cadez \& Guilding, 2008; Guilding, 1999; Guilding \& McManus, 2002; Malmi, Raulas, Gudergan, \& Sehm, 2004), and such methods tend to increase the possibility of bias (McManus \& Guilding, 2008).

Furthermore, the majority of previous studies did not give sufficient attention to nonfinancial indicators, but focused on financial performance or overall performance, a practice widely criticised due to its internal and historical focus, which is more likely to be manipulated by managers (Hoque, Mia, \& Alam, 2001; Johnson \& Kaplan, 1987). Those financial measurements are considered as not to give a clear picture of an organization's performance, unless it is coupled with non-financial indicators (Chenhall \& Langfield-Smith, 2007; Kaplan, 1984). Furthermore, a few studies in the literature have examined the link between SMA and company performance presented inconsistent results (Cades \& Gailding, 2008; Mulmi et al., 2004; O'Conner \& Cheang, 2007).

\subsection{Relationship between SMA and Company's Performance}

The direct link between information use and Company's performance has been assumed in many areas, such as in the field of management information systems (Vandenbosch \& Huff, 1997), and in marketing (Diamantopoulos \& Souchon, 1998; Moorman, 1995). However, this assumption has mostly been confirmed in the management accounting 
systems literature as well (Cades \& Gailding, 2008; Ashford \& Cumings, 1983; Baines \& Lungfield-Smith, 2003; Chong \& Chong, 1997; Jusoh et al., 2008; Mia \& Clarke, 1999; Noone \& Griffin, 1997). These studies have hypothesized a direct link between MAI and performance. Even the study conducted by Henri (2006), who deliberately assumed an indirect link between utilize of MAI and performance, the empirical data did actually provide support for a direct relationship.

The common assumption regarding the direct link between MAI usage and company's performance has been supported by most of the studies that have been examined. The assumption on the direct relationship between information use and performance, especially, the positive influence of information use on the performance is that the extent of management accounting information usage influence effectiveness in decision making and organizational performance (Baines \& Langfaeld Smith, 2003; Chong \& Chonge, 1997; Cades \& Gailding, 2008; Henri, 2006; Noone \& Griffin 1997). For example, Cadez and Guilding hypothesized the direct link between SMA usage and a company's performance and they gave the rational link for this relationship. They argued that major idea of an accounting information system is to provide information to help the managers in the implementation of plans, completion of their job, support the mangers in the decision-making process, and to enhance organizational performance.

Chong and Chong (1997) have hypothesized the direct link between the MAS usage of the information and company's performance; they assumed that MAS information would aid the managers in their decision-making process and enhance the organizational performance. Then, Henri (2006) investigated the direct association between the usage of management control system and organizational performance. In his study, Henri implicitly assumed that the usage of management accounting information for decision making has a positive effect on organizational performance. In addition, Jais (2007) also assumed a direct link between the usage of management accounting information and performance. According to Baines and Langfield-Smith management accounting information helps managers reach informed decisions and enhance organizational performance. A negative relationship was found by Ittner and Larcher (1997) between a number of control practices including market studies, the benchmarking, and strategic audits from one hand and company performance from the other. Chong and Chonge (1997) argued that MAS as playing the main role in the link between choices of the strategy and company performance. The work revealed that a broad scope of MAS usage positively affects company performance. Gul and Huang (1992) have tested the link between MAS and company performance, and they found that there is a significant and positive link between MAS and company performance.

Furthermore, some studies (e.g., Agbejale, 2005; Perrera et al., 1997; Itner \& Larcker, 1997) demonstrated a negative and also no impact of the information of accounting practices on company performance. For instance, Ittner and Larcker found a negative effect of several strategic control practices on performance, and Perrera et al. found no relationship between the usage of nonfinancial performance measurements and performance. Moreover, Mulmi et al. (2004) investigated the impact of profitability of the customers on company performance, and they found there is no effect on performance.

Another study done by Perrera, Harrison, and Poole (1997) confirmed that there was no relationship between the use of nonfinancial measures and performance. Furthermore, Ittner et al. (2003) reported that the broad use of information was positively associated with stock returns but was not associated with return on assets and sales growth. While, Agbejule (2005) reported that negative effect of management accounting system on 
performance, Abernethy \& Guthrie (1995) found that the effect of the usage of management accounting system information on the organizational performance depends on the business strategy.

Most of the results refer to a positive connection regarding the utilization of AI and company financial performance while previous studies provided mixed results. The rational justification behind hypothesizing the direct link between CA and company performance was based on the basic notion promoted by previous accounting studies. Accounting studies in the literature review have maintained that one of the key roles of AIS is the implementation and development of business strategy (Chanhall, 2003). In that, AI can maintain the strategy of business and also develop monitor the functioning of these strategies and achieving high performance (Govindarjan \& Gapta, 1985; Simon, 1987). In the present's study context, it is essential to recognize and focus on the quality of SMA, mainly in presenting important and incremental information for strategic purposes which could not be collected by the conventional AIS. These perspectives have motivated the present work to propose this hypothesis.

H1: There is a significant and positive link between SMA information usage and financial performance.

\section{Methodology}

The sample size for the present work is 127 service firms listed on the Amman Stock Exchange. This study uses a quantitative method; the variables are measured based on a questionnaire. SPSS Ver. 20.0 is used in analysing data. The collection of data went through several statistical techniques like (Descriptive, Correlations and Multiple Regressions Analysis).

\subsection{Measurements of Variables}

The measurements used to measure the variables of the current work were developed and adapted. The tool represented by a survey for the items related to the perception of the respondents of SMA information. The current study conceptualized SMA as the level of the use of external information of accounting in link to the company's customers, namely customer profit analysis, lifetime customer profit analysis, valuation of customers as assets, and customer equity analysis. Thus, the present work has developed 29 items as a measurement of the level of SMA information usage and the availability. Two scales were used for the listed items; seven point scale, where $1=$ Not at all used, to $7=$ Greatly used, to find out the level of SMA usage of information.

Financial performance measurement involves (ROE, ROI, rate of sales growth, and Operating Profit). These measurements are used by previous studies in the literature review (Chanhall \& Langfeild Smith, 2007; Hoque \& Jemes, 2000; Govandarajan, 1988;). The measurements of the study scale were evaluated for construct and content the validity, whereas the scales reliability was assessed by using Cronbach alpha.

\subsection{Control Variable}

To avoid the impact of omitted variable bias (Alabdullah et al, 2014), there are two control variables used in the present study. That is based on several studies that have been done previously in MAS and also related studies (Cades, 2006; Gailding et al., 2000; Dess, Ireland, \& Hit, 1990). The control variables were included in the analysis due to their importance (Guost, 2001). Moreover, there will be a case of misleading if the studies ignore using control variables in the their studies (Foss \& Knadsen, 2003). 
Thus, to remove the impact influencing the relationships under study, the study introduced control variables to avoid the potential impact of company and industry size.

The company size variable is important to capture size and scale effects because large organizations may be more likely to have well-developed and sophisticated AIS compared with small companies (Gailding et al., 2000; Bains \& Langfeild Smith, 2003). The accounting literature also argued that analysis of this type must control for size (Simarly \& Li, 2000; Govindarajan, 1988). The current study also included Firm size is as a control variable due to in contingency theory research it is frequently mentioned to be a variable effecting MAS design. Larger companies are more willing to use accounting sophistication as demonstrated by previous studies (Gailding et al., 2000; Cinqueni \& Tenuci, 2010). Therefore, to be considered SMA as advanced accounting techniques it might be expected to have an effect on financial performance. In the current work the company size as a control variable is measured as a number employees in the company.

With regard to the type of industry (second control variable), the effect of industry type is pervasive across all sectors of the service industry and has a big categorical effect on organizational performance (Terziovski \& Samson, 1999).

\subsection{Descriptive Statistics}

The table shows that financial performance was high in organizational performance (mean $=4.56, \mathrm{SD}=1.55)$. On the other hand, the table revealed that the mean SMA is mean $=4.26, \mathrm{SD}=1.46)$.

Table 1.1 Descriptive statistics of variables

\begin{tabular}{|l|c|c|}
\hline Variables & Mean & Std Deviation \\
\hline SMA & 4.26 & 1.46 \\
\hline F-P & 4.56 & 1.55 \\
\hline
\end{tabular}

Note: All the variables were measured through utilizing 7-point Likert-scale with $(1=$ not at all, and the $7=$ to a greater extent $)$

\subsection{Correlation Analysis}

In order to determine the degree to which the variables are related, correlation analyses were used. It shows how the estimated equation is well in describing the links (Leven $\&$ Ruben, 2007). The test of correlation between SMA and F-P is explained in Table 4. The report revealed that SMA have a positive link with F-P, with values (.310).

Table 1.2 Correlations Analysis

\begin{tabular}{|l|c|c|}
\hline & SMA & F-P \\
\hline SMA & 1 & \\
\hline F-P & .310 & $\mathbf{1}$ \\
\hline
\end{tabular}

**. Correlation is significant at the level of 0.01 ( 2 tailed).*. Correlation also is significant with the level of 0.05 (2 tailed).

\subsection{Regression Analysis}

To test hypotheses that postulated a positive relationship between independent variables (SMA) and dependent variable (financial performance), there was one step of hierarchical regression equation that was carried out. It is represented by the 
independent variables which were introduced to investigate marginal impact on the dependent variables.

Table 1.3 shows the value of $\mathrm{R}$ square of .130 for SMA, the value of $\mathrm{R}$ square explained 13. \% from the independent variables on the dependent variable (Financial Performance).

Table 1.3 R Square of SMA

\begin{tabular}{|l|c|}
\hline \multicolumn{1}{|c|}{ Model } & SMA \\
\hline R-Square & 0.130 \\
\hline Sig F-Change & 0.000 \\
\hline
\end{tabular}

Table 1.4 showed that SMA has positive relationship with the financial performance, (-.189). The finding revealed that internal review has a significant effect on financial performance that it was at $\mathrm{P}<0.01, \beta=0.191$. It reveals that the larger the information of SMA, the higher performance. Thus, the hypothesis is supported. This result gives support for the conclusion that the SMA features lead to the creation of financial performance.

Table 1.4 Regression Test: link between SMA and Financial Performance

\begin{tabular}{|l|c|}
\hline \multicolumn{2}{|c|}{ Financial Performance } \\
\hline \multicolumn{2}{|c|}{ Standardized Coefficients } \\
\hline Independent Variable & Beta \\
\hline SMA & .191 \\
\hline
\end{tabular}

The analysis shows that the hypothesis set by the current work regarding its proposed variables is accepted.

\section{The Impact of SMA and Financial Performance}

SMA is an important factor affecting organization performance (Cadez \& Guilding, 2008; Baines \& Langfield-Smith, 2003). The current study evaluated the level of financial performance of Jordanian service companies. The current study makes a contribution to the literature via offering detailed evidence of the financial performance level of these companies. The level of performance of service companies in Jordan was shown by using descriptive statistics. The results of the current study drew conclusions regarding the financial performance of Jordanian service companies that contributes to the existing research. Financial performance, measured by monetary metrics (such as ROE, ROI, and operating profit), was rated higher than other performance dimensions and indicated that Jordanian service companies ranked financial performance rated as above average. This result is expected, as the main goal of business is profit maximisation. Nevertheless, a closer look at the characteristics of Jordanian service companies showed that about $40 \%$ of the companies had been in operation for more than three years, which suggests the companies are well established and stable in Jordan. Such well-established companies normally have relatively higher financial performance.

This result was justified by the World Competitiveness Yearbook, 2009, which showed that Jordanian companies have had stable financial performance for the last few years. 
However, there are increasing criticisms that the financial performance measurement system relies solely on performance measurements, which are focused on internal and historical aspects rather than having external focus and being future-oriented. In addition, previous studies have pointed out that the role of short-term financial performance measurement systems have been undermined by rapid changes in technology and competitive business environment (Chenhell \& Langfield-Smith, 2007; Johnsen \& Kaplan, 1987), and organizational performance should also be evaluated on nonfinancial performance measurements which are considered as leading indicators to future financial performance. In the current study, market performance indicators. Jordanian services companies ranked market performance highest, after financial performance, with mean value of 4.56, which indicates market performance was rated above average. In addition, the qualitative results rated the market performance in the second rank after financial performance. However, the relatively low market performance level among Jordanian service companies could be a result of the dynamic actions that have been taking place in the Jordanian market, making the process of estimating a firm's market performance difficult, costly, and time consuming. These findings from the present study are in line with that of some previous studies (Guilding \& McManus, 2002; O'Connor \& Cheung, 2007) and contrasted with other works on accounting technique usage, such as that of Lord, Shanahan and Nolan (2007) who found that customer accounting technique usage was below the midpoint on a 7-point Likert scale, and that of Cadez (2006) who found that two out of three customer accounting techniques measured below the midpoint on a 7-point Likert scale. Their research design may explain the reasons for their findings. There are also other strategic management accounting studies that contrasted the current study's findings (Guilding, 1999; Gualding et al., 2000). However, the potential explanation is that over the last decade, service companies had started to appreciate the usefulness of SMA information for strategic decision making purposes. Also, the study findings showed that accounting information has definitely made progress. Generally, the results of the present study leads to conclusions about the reality of SMA usage in Jordanian service companies, which previous studies had failed to discover.

SMA information usage has been hypothesized to have significant and positive effects on customer-based performance. Several reasons can justify these insignificant results. First, as noted by the low mean value, customer-based performance among Jordanian service companies is low compared with financial and market performance. Furthermore, the insignificant results could be justified by looking at the weak correlations between customer-based performance and SMA information dimensions, namely analysis of customer profitability, analysis of lifetime customer profitability, customers valuation, and customer retention was not significant. This insignificant relationship could be the result of weak correlations as indicated by Cohen's rule (1988). The theoretical justification behind the insignificant results might be because of the unclear nature of the relationships between usage of the non-financial information and performance. The majority of previous studies still consider this relationship as an ambiguous relationship (Bainis \& Langfeld-Smith, 2003). The majority of previous studies supported the notion of such a relationship. Another justification regarding such a result is that the application of strategic MAI is not a condition related to outstanding performance; but, outstanding performance is a product of the suitable implementation of SMA given suitable contingent factors (Cadiz \& Gailding, 2008). 


\section{Implications}

The current study's theoretical contributions offer a significant advancement on the current SMA information systems literature. The operationalisation of SMA is another important issue that has been neglected in previous studies; not to mention that too few instruments of measurement are available with no development being notified in the literature regarding such issue.

Moreover, these instruments of measurement were developed in the literature to determine customers accounting techniques rather than SMA information usage. To date, the best measurement scale has been developed by Guilding and McManus (2002). However, its weakness was that customer's accounting techniques were measured by one single question, which could possibly cause bias in the measurement scale (McManus \& Guilding, 2008). Apart from that, it was focused on techniques rather than information usage. Thus, it could not give a valid and clear measurement. On this point, the findings of the current study have contributed to the existing body of the knowledge, particularly on how SMA can be conceptualised and operationalised within the service industries environment.

Furthermore, another theoretical contribution of the present work is related to the inclusion of the performance consequences of SMA information usage. So far, little empirical evidence has been presented about SMA information usage and its association with company's performance. The findings of the current research provide some evidence that the information from SMA usage has a positive impact on non-financial and financial performance. Consequently, the current study provides empirical evidence to support the link between SMA information usage and organizational financial and non-financial performance within the Jordanian context in its service companies. Therefore, findings of the present work help service company management understand the significance of AI for strategic decision making. Alternatively, the practical implications of the present work, most accounting and management academics consider the practical implications as a vital thing that academic and scholar research identifies its relevance and implications to practice. Thus, the current paper presents such implications and its usefulness for practitioners, primarily top management of service sector.

\section{Conclusions}

There has been no single previous study in the accounting literature, that investigated the components of SMA dimensions, the level of their usage, and their impact on company's performance. The present work has made a distinctive contribution that might be added to the body of literature regarding the impact of SMA on the financial performance of Jordanian service companies. This study provides results revealing the SMA level in service companies in Jordan that is high in general. This work revealed there is empirical evidence showing the independent variable effect of an SMA on companies' performance. The current study demonstrated that SMA might be provided to Jordanian service firms with distinctive strategic information that underpinned the development of their market strategy and improved their company's performance. The strategic SMA elements that affect the company performance of service companies, and thus deserve to have more attention are customer profitability analysis, analysis of lifetime customer profitability, valuation of customers, analysis of customer equity, and analysis of customer retention. Thus, the firms should recognize the powerful effect SMA may have on company performance. 
The current work tested a research model that is conceptualized as the impact of SMA on Jordanian service companies' performance. The research could find that the selected SMA impact on performance might be used as a reference by two groups of people to improve the quality of their financial performance. These groups are companies' managers and decision makers in the relevant regulatory authorities. It could help both groups to strategize about improving financial performance in firms by controlling the selected characteristics, and hence help service company management to understand the importance of accounting information for strategic decision making.

\section{References}

Abdel-Maksoud, A., Cheffi, W., \& Ghoudi, K. (2016). The mediating effect of shopfloor involvement on relations between advanced management accounting practices and operational non-financial performance indicators. The British Accounting Review, 48(2), 169-184. https://doi.org/10.1016/j.bar.2015.10.002

Abernethy \& Bouwens. (2005). Determinants of accounting innovation implementation. Abacus, 41(3), 217-240.

https://doi.org/10.1111/j.1467-6281.2005.00180.x

Abernethy, M. A. \& Lillis, A. M. (1995). The impact of manufacturing flexibility on management control system design. Accounting, Organizations and Society, 20(4), 241-258. https://doi.org/10.1016/0361-3682(94)E0014-L

Agbejule, A. (2005). The relationship between management accounting systems and perceived environmental uncertainty on managerial performance: A research note. Accounting and Business Research, 35(4), 295-305. https://doi.org/10.1080/00014788.2005.9729996

Alabdullah, T. T. Y. (2018). The Relationship Between Ownership Structure and Firm Financial Performance: Evidence from Jordan. Benchmarking: An International Journal, 25(1), 1-17. https://doi.org/10.1108/BIJ-04-2016-0051

Alabdullah, T.T.Y., Yahya, S., \& Ramayah, T. (2014). Corporate governance mechanisms and Jordanian companies' financial performance. Asian Social Science, 10(22), 247-262. https://doi.org/10.5539/ass.v10n22p247

Ashford, S. J. \& Cummings, L. L. (1983). Feedback as an individual resource: Personal strategies of creating information. Organizational Behavior and Human Performance, 32(3), 370-398. https://doi.org/10.1016/0030-5073(83)90156-3

Baines, A. \& Langfield-Smith, K. (2003). Antecedents to management accounting change: A structural equation approach. Accounting, Organizations and Society, 28(7-8), 675-698. https://doi.org/10.1016/S0361-3682(02)00102-2

Becker, B. \& Gerhart, B. (1996). The impact of human resource management on organizational performance: Progress and prospects. The Academy of Management Journal, 39(4), 779-801. https://doi.org/10.2307/256712

Begum, H., Alam, M. R., Alam, A., \& Awang, A. H. (2015). Islamic microfinance as an instrument for poverty alleviation. Advanced Science Letters, 21(6), 1708-1711. https://doi.org/10.1166/asl.2015.6123

Belkaoui, A. (1980). Conceptual foundations of management accounting. Reading, MA: Addison-Wesley. 
Bromwich, M. (1990). The case for strategic management accounting: The role of accounting information for strategy in competitive markets. Accounting, Organizations and Society, 15(1-2), 27-46. https://doi.org/10.1016/0361$\underline{3682(90) 90011-\mathrm{I}}$

Budiarto, D. S., Rahmawati., Prabowo, M. A., Bandi., Djajanto, L., Widodo, K. P., \& Herawan, T. (2018). Accounting Information System (AIS) Alignment and Non-financial Performance in Small Firm: A Contingency Perspective. Paper presented at the International Conference on Computational Science and Its Applications. Melbourne, Springer.382-394. https://doi.org/10.1007/978-3-31995165-2_27

Bromwich, M. \& Bhimani, A. (1994). Management accounting: Pathways to progress. Chartered institute of management accountants, London.

Cadez, S. (2002): Strategic Management Accounting: Conceptual Framework and Empirical Evidence from Slovenian Companies, in: Economic and Business Review, 4, 2, 129-157.

Cadez, S. (2006). A cross industry comparison of strategic management accounting practices: An exploratory study. Economic and Business Review for Central and South-Eastern Europe, 8(3), 279-299.

Cadez, S., \& Guilding, C. (2008). An exploratory investigation of an integrated contingency model of strategic management accounting. Accounting, Organizations and Society, 33(7-8), 836-863. https://doi.org/10.1016/j.aos.2008.01.003

Cohen, J. (1988). Statistical power analysis for the behavioral sciences. Mahwah, NJ: Lawrence Erlbaum Associates.

Cravens, K. S. \& Guilding, C. (2001). An empirical study of the application of strategic management accounting techniques. Advances in Management Accounting, 10, 95-124.

Chenhall, R. H. (2003). Management control systems design within its organizational context: Findings from contingency-based research and directions for the future. Accounting, Organizations and Society, 28(2-3), 127-168. https://doi.org/10.1016/S0361-3682(01)00027-7

Chenhall, R. H. \& Langfield-Smith, K. (2007). Multiple perspectives of performance measures. European Management Journal, 25(4), 266-282. https://doi.org/10.1016/j.emj.2007.06.001

Dearman, D., Lechner, T. A., \& Shanklin, S. B. (2018). Demand for management accounting information in small businesses: Judgment performance in business planning. International Journal of the Academic Business World, 12(1), 93-102.

Dess, G. G., Ireland, R. D., \& Hitt, M. A. (1990). Industry effects and strategic management research. Journal of Management, 16(1), 7. https://doi.org/10.1177/014920639001600102

Dess \& Robinson, J. R. B. (1984). Measuring organizational performance in the absence of objective measures: The case of the privately held firm and conglomerate business unit. Strategic Management Journal, 5(3), 265-273. https://doi.org/10.1002/smj.4250050306

Duursema, N. (1999). Balancec scorecard performance measurement for cost engineering. Transactions, 08.01 .

Franco-Santos, M., Kennerley, M., Micheli, P., Martinez, V., Mason, S., Marr, B., et al. (2007). Towards a definition of a business performance measurement system. International Journal of Operations \& Production Management, 27(8), 784-801. https://doi.org/10.1108/01443570710763778 
Ferris, K. R. \& Haskins, M. E. (1988). Perspectives on accounting systems and human behaviour. Accounting, Auditing \& Accountability Journal, 1(2), 3-18. https://doi.org/10.1108/EUM0000000004621

Foss, N. J., \& Knudsen, T. (2003). The resource-based tangle: Towards a sustainable explanation of competitive advantage. Managerial and Decision Economics, 24(4), 291-307. https://doi.org/10.1002/mde.1122

Forza, C., \& Salvador, F. (2000). Assessing some distinctive dimensions of performance feedback information in high performing plants. International Journal of Operations \& Production Management, 20(3), 359-385. https://doi.org/10.1108/01443570010308112

Chong, V. K. \& Chong, K. M. (1997). Strategic choices, environmental uncertainty and SBU performance: A note on the intervening role of management accounting systems. Accounting and Business Research, 27, 268-276. https://doi.org/10.1080/00014788.1997.9729553

Cinquini, L. \& Tenucci, A. (2010). Strategic management accounting and business strategy: A loose coupling? Journal of Accounting \& Organizational Change, 6(2), 228-259. https://doi.org/10.1108/18325911011048772

Cooper, R. \& Kaplan, R. S. (1988). Measure costs right: Make the right decisions. Harvard Business Review, 66(5), 96-103.

Diamantopoulos, A. \& Souchon, A. L. (1998). Information utilisation by exporting firms: Conceptualisation, measurement, and impact on export performance. Information and Management: Utilization of Technology-Structural and Cultural Impact, Gabler, Wiesbaden, 111-140. https://doi.org/10.1007/978-3-32286995-1_5

Drury, C. (2007). Management and cost accounting: Cengage Learning EMEA.

Gordon \& Narayanan. (1984). Management accounting systems, perceived environmental uncertainty and organization structure: An empirical investigatio. Accounting, Organizations and Society, 9(1), 33-47. https://doi.org/10.1016/0361-3682(84)90028-X

Govindarajan, V. (1988). A contingency approach to strategy implementation at the business-unit level: Integrating administrative mechanisms with strategy. The Academy of Management Journal, 31(4), 828-853. https://doi.org/10.2307/256341

Govindarajan, V. \& Gupta, A. K. (1985). Linking control systems to business unit strategy: Impact on performance. Accounting, Organizations and Society, 10(1), 51-66. https://doi.org/10.1016/0361-3682(85)90031-5

Guilding, C., Cravens, K. S., \& Tayles, M.(2000). An international comparison of strategic management accounting practices. Management Accounting Research, 11(1), 113-135. https://doi.org/10.1006/mare.1999.0120

Guilding, C., Kennedy, D. J., \& McManus, L. (2001). Extending the boundaries of customer accounting: Applications in the hotel industry. Journal of $\begin{array}{lllll}\text { Hospitality } \& \quad \text { Tourism } & \text { Research, }\end{array}$ https://doi.org/10.1177/109634800102500205

Guilding, C. \& Pike, R. (1990). Intangible marketing assets: a managerial accounting perspective. Accounting and Business Research, 21(18), 41-49. https://doi.org/10.1080/00014788.1990.9729402

Guilding, C. \& McManus, L. (2002). The incidence, perceived merit and antecedents of customer accounting: an exploratory note. Accounting, Organizations and Society, 27(1-2), 45-59. https://doi.org/10.1016/S0361-3682(01)00030-7

Gul, Glen, W., \& Huang, A. (1992). The effect of computer usage, environmental uncertainty and management accounting systems on small business performance. Malaysian Management Journal, 1(1), 35-45. 
Harris, P. J. \& Mongiello, M. (2001). Key performance indicators in European hotel properties: General managers ${ }^{\text {ee }}$ choices and company profiles. International Journal of Contemporary Hospitality Management, 13(3), 120-128. https://doi.org/10.1108/09596110110388909

Henri, J. F. (2006). Management control systems and strategy: A resource-based perspective. Accounting, Organizations and Society, 31(6), 529-558. https://doi.org/10.1016/j.aos.2005.07.001

Hoque, Z. (2005). Linking environmental uncertainty to non-financial performance measures and performance: A research note. The British Accounting Review, 37(4), 471-481. https://doi.org/10.1016/j.bar.2005.08.003

Hoque, Z., \& James, W. (2000). Linking balanced scorecard measures to size and market factors: Impact on organizational performance. Journal of Management Accounting Research, 12, 1-18. https://doi.org/10.2308/jmar.2000.12.1.1

Hoque, Z., Mia, L., \& Alam, M. (2001). Market competition, computer-aided manufacturing and use of multiple performance measures: An empirical study. British Accounting Review, 33(1), 23-46. https://doi.org/10.1006/bare.2000.0149

Horngren, C. T. (2004). Management accounting: Some comments. Management Accounting, 207-211. https://doi.org/10.2308/jmar.2004.16.1.207

Ittner, C. D., Larcker, D. F., \& Randall, T. (2003). Performance implications of strategic performance measurement in financial services firms. Accounting, Organizations and Society, 28(7-8), 715-741. https://doi.org/10.1016/S03613682(03)00033-3

Ittner, C. D. \& Larcker, D. F. (1997). Quality strategy, strategic control systems, and organizational performance. Accounting, Organizations and Society, 22(3-4), 293-314. https://doi.org/10.1016/S0361-3682(96)00035-9

Ittner, C. D. \& Larcker, D. F. (1998). Are nonfinancial measures leading indicators of financial performance? An analysis of customer satisfaction. Journal of Accounting Research, 36, 1-35. https://doi.org/10.2307/2491304

Jais, S. D. (2007). The Successful Use of Information in Multinational Companies: An Exploratory Study of Individual Outcomes and the Influence of National Culture: Springer.

Jermias, J., \& Gani, L. (2004). Integrating business strategy, organizational configurations and management accounting systems with business unit effectiveness: a fitness landscape approach. Management Accounting Research, 15(2), 179-200. https://doi.org/10.1016/j.mar.2004.03.002

Johnson, H. T., \& Kaplan, R. S. (1987). Relevance lost: The rise and fall of management accounting. Boston, MA: Harvard Business Press.

Jusoh, R., Ibrahim, D. N., \& Yuserrie, Z. (2008). The performance consequence of multiple performance measures usage: Evidence from the Malaysian manufacturers. International Journal of Productivity and Performance Management, 57(2), 119-136. https://doi.org/10.1108/17410400810847393

Kaplan, R. S. (1983). Measuring manufacturing performance: A new challenge for managerial accounting research. The Accounting Review, 58(4), 686-705.

Kaplan, R. S., \& Narayanan, V. (2001). Customer profitability measurement and management. Boston, MA: Harvard Business School, May 1, ss. 1, 12.

Kaplan, R. S., \& Norton, D. P. (1992). The balanced scorecard: Measures that drive performance. Harvard Business Review, 70(1), 71-79.

Kaplan, R. S., \& Norton, D. P. (1996). The balanced scorecard: translating strategy into action: Boston, MA: Harvard Business Press. 
Langfield-Smith, K. (1997). Management control systems and strategy: A critical review. Accounting, Organizations and Society, 22(2), 207-232. https://doi.org/10.1016/S0361-3682(95)00040-2

Latha, C. M. (2016). Role of service sector in economic development of Karnataka with special reference to Mandya District.

Lord, B. R. (1996). Strategic management accounting: The emperor's new clothes? Management Accounting Research, 7(3), 347-366. https://doi.org/10.1006/mare.1996.0020

Lord, B. R., Shanahan, Y. P., \& Nolan, B. M. (2007). The use and perceived merit of customer accounting in New Zealand. Accounting Research Journal, 20(1), 4759. https://doi.org/10.1108/10309610780000689

Maas, K., Schaltegger, S., \& Crutzen, N. (2016). Integrating corporate sustainability assessment, management accounting, control, and reporting. Journal of Cleaner Production, 136, 237-248. https://doi.org/10.1016/j.jclepro.2016.05.008

March, J. G., \& Sutton, R. I. (1997). Organizational performance as a dependent variable. Organization Science, 698-706. https://doi.org/10.1287/orsc.8.6.698

Malmi, T., Raulas, M. and Sehm, J. (2004) An empirical study on customer profitability accounting, customer strategies and corporate performance, Paper presented at European Accounting Association Conference, Praque, 2004, 1 - 22.

McManus, L., \& Guilding, C. (2008). Exploring the potential of customer accounting: A synthesis of the accounting and marketing literatures. Journal of Marketing Management, 24(7), 771-795. https://doi.org/10.1362/026725708X345515

Miani, S. \& Daradkah, D. (2008). The banking industry in Jordan. Transition Studies Review, 15(1), 171-191. https://doi.org/10.1007/s11300-008-0168-1

Mia, \& Patiar, A. (2001). The use of management accounting systems in hotels: An exploratory study. International Journal of Hospitality Management, 20(2), 111128. https://doi.org/10.1016/S0278-4319(00)00033-5

Moorman, C. (1995). Organizational market information processes: Cultural antecedents and new product outcomes. Journal of Marketing Research, 32(3), 318-335. https://doi.org/10.1177/002224379503200307

Nyasha, S.; Odhiambo, N. Financial Development and Economic Growth Nexus: A Revisionist Approach. Rev. Bank. Financ. Monet. Econ. 2018, 47, 223-229. https://doi.org/10.1111/ecno.12101

Neely, A., Gregory, M., \& Platts, K. (1995). Performance measurement system design: A literature review and research agenda. International Journal of Operations \& Production Management, 15(4), 80-116. https://doi.org/10.1108/01443579510083622

Noone, B., \& Griffin, P. (1997). Enhancing yield management with customer profitability analysis. International Journal of Contemporary Hospitality Management, 9(2), 75-79. https://doi.org/10.1108/09596119710164812

O'Connor, N. G. \& Cheung, C. L. K. (2007). Product/service adoption strategies and bank customer accounting in Hong Kong. Pacific Accounting Review, 19(1), 31-46. https://doi.org/10.1108/01140580710754638

Otley, D. (1999). Performance management: A framework for management control systems research. Management Accounting Research, 10(4), 363-382. https://doi.org/10.1006/mare.1999.0115

Pradhan, D., Swain, P. K., \& Dash, M. (2018). Effect of management accounting techniques on supply chain and firm performance: An empirical study. International Journal of Mechanical Engineering and Technology, 9(5), 1049-1057. 
Perera, S., Harrison, G., \& Poole, M. (1997). Customer-focused manufacturing strategy and the use of operations-based non-financial performance measures: A research note. Accounting, Organizations and Society, 22(6), 557-572. https://doi.org/10.1016/S0361-3682(96)00048-7

Roslender, R. \& Hart, S. J. (2002). Integrating management accounting and marketing in the pursuit of competitive advantage: The case for strategic management accounting. Critical Perspectives on Accounting, 13(2), 255-277. https://doi.org/10.1006/cpac.2001.0477

Reinartz, \& Kumar, V. (2003). The impact of customer relationship characteristics on profitable lifetime duration. The Journal of Marketing, 67(1), 77-99. https://doi.org/10.1509/jmkg.67.1.77.18589

Sinkey, J. F. (1983). Commercial bank financial management. New York: Macmillan.

Simons, R. (1987). Accounting control systems and business strategy: An empirical analysis. Accounting, Organizations and Society, 12(4), 357-374. https://doi.org/10.1016/0361-3682(87)90024-9

Simmonds, K. (1981). Strategic management accounting. Management Accounting, 59(4), 26-29.

Tiessen, P. \& Waterhouse, J. H. (1983). Towards a descriptive theory of management accounting. Accounting, Organizations and Society, 8(2-3), 251-267. https://doi.org/10.1016/0361-3682(83)90033-8

Tomkins, C., \& Carr, C. (1996). Reflections on the papers in this issue and a commentary on the state of strategic management accounting. Management Accounting Research, 7(2), 271-280. https://doi.org/10.1006/mare.1996.0015

Vandenbosch, B., \& Huff, S. L. (1997). Searching and scanning: How executives obtain information from executive information systems. Mid-quarterly, 81-107. https://doi.org/10.2307/249743

Terziovski, M. \& Samson, D. (1999). The link between total quality management practice and organisational performance. International Journal of Quality \& Reliability Management, 16(3), 226-237. https://doi.org/10.1108/02656719910223728

Venkatraman, N. \& Ramanujam, V. (1986). Measurement of business performance in strategy research: A comparison of approaches. The Academy of Management Review, 11(4), 801-814. https://doi.org/10.5465/amr.1986.4283976

Ward, K. (1992). Strategic management accounting. Oxford: Butterworth- Heinemann.

Wilson, R. M. S. (1995). Strategic management accounting. Issues in Management Accounting, 2, 159-190. 